Original Paper

\title{
Pengembangan Bahan Ajar dan LKPD IPA untuk Meningkatkan Kompetensi Literasi Sains Bagi Guru Anggota MGMP IPA SMP di Kota Mataram
}

\author{
Dadi Setiadi $^{1}$, A. Wahab Jufri ${ }^{1}$, Agus Ramdani ${ }^{1}$, Jamaluddin ${ }^{1 *}$, Imam Bachtiar $^{1}$ \\ ${ }^{1}$ Program Studi Pendidikan Biologi, Fakultas Keguruan dan Ilmu Pendidikan, Indonesia
}

DOI: $10.29303 /$ jpmpi.v2i2.372

Sitasi: Setiadi, D, Jufri, A. W, Ramdani, A., Jamaluddin ${ }^{1 *}$, Bachtiar, I. (2019). Pengembangan Bahan Ajar dan LKPD IPA untuk Meningkatkan Kompetensi Literasi Sains Bagi Guru Anggota MGMP IPA SMP di Kota Mataram. Jurnal Pengabdian Magister Pendidikan IPA (JPMPI). (2) 2. pp. 127-132

*Corresponding Author: Jamaluddin, Program Studi Pendidikan Biologi, Fakultas Keguruan dan Ilmu

Pendidikan, Indonesia; Email:

jamaluddin_fkip@unram.ac.id
Abstrak: Pengembangan kompetensi literasi sains merupakan hal yang penting dalam membekali peserta didik di tingkat satuan pendidikan menengah pertama/SMP. Kompetensi tersebut merupakan dasar untuk pengembangan tagihan kompetensi kurikulum 2013 SMP termasuk didalamnya adalah proses dan evaluasi hasil belajar. Selain itu kurikulum 2013 mata pelajaran IPA SMP 2013 menagih peserta didik untuk bisa memiliki keterampilan berpikir tinggi dan kreatif dimana didalamnya termasuk kemampuan literasi sains. Untuk mencapai tujuan tersebut perlu didukung adanya bahan ajar dan LKPD yang dapat mengarahkan peserta didik memiliki kemampuan literaisi sains. Tujuan kegiatan pengabdian yang akan dilakukan adalah Mengembangkan pemahaman guru an Hasil menunjukan bahwa peserta workshop guru-guru SMP mata pelajaran IPA memiliki pemahaman sangat baik dan komprehensif terkait dengan pemahaman bagaimana menysusun bahan ajar dan LKPD yang dapat meningkatkan kemampuan literasi sains peserta didik SMP dalam pelajaran IPA. Selain itu para peserta telah memiliki keterampilan dalam menyusun bahan ajar dan LKPD yang dapat keningkatkan kemampuan literasi sains peserta didik. Tetapi tim pengabdian harus terus mendampingi para guru tersebut sampai betul betul terampil dalam menyusun bahan ajar LKPD sampai dengan merevisi ketika digunakan dan mengembangkannya agarn hasil tersebut bisa memberikan manfaat dalam meningkatkan kemampuan peserta didik.Kemampuan para peserta workshop yang cukup baik dalam menyusun bahan ajar dan LKPD mata pelajaran IPA bisa memberikan kontribusi dalam meningkatkan kualitas pembelajaran IPA di SMP di Kota Mataram khususnya dalam mengembangkan kemampuan literasi sains peserta didik. Selain itu bahan ajar dan LKPD perlu tetap dikembangkan disesuaikan dengan kondisi peserta didik dan tagihan hasil belajar mata pelajaran IPA di SMP di masa sekarang dan akan dating sehingga kompetensi peserta didik sesuai dengan yang dibutuhkan dan kondisi perkembangan ilmu pengetahuan dan teknologi.ggota MGMP IPA Kota Mataram dalam menyusun bahan ajar dan LKPD yang dapat meningkatkan kemamapuan literasi sains; Mengembangkan keterampilan guru guru anggota MGMP IPA Kota Mataram dalam menyusun LKPD yang dapat meningkatkan kemampuan literasi sains. Metode yang digunakan dalam pengabdian ini adalah melalui workshop yang lebih berbasis pada praktek langsung menyusun dan mendisain bahan ajar dan LKPD yang dapat meningkatkan kemampuan literasi sains.

KataKunci : literasi Sains; Bahan ajar; LKPD.

\section{Pendahuluan}

Tagihan kurikulum 2013 khususnya dalam mata pelajaran IPA SMP cukup tinggi dibandingkan dengan kurikulum sebelumnya seperti halnya dalam kompetesi inti 3 dan 4 . Oleh karena itu guru harus mampu menginterpretasi apa yang ditagih oleh isi kurikulum yang menyangkut 4 komptetensi inti tersebut terkait dengan bahan ajar dan kegiatan terkait dengan LKPD. Jika salah 
dalam menginterpretasi tagihan isi yang diminta tidak akan mencapai tujuan yang diharapkan dari kurikulum 2013. Keterampilan guru dalam menyusun materi pembelajaran tidak hanya dalam hal mengembangkan pengetahuan tetapi juga dalam hal keterampilan dan sikap. Oleh krena itu guru harus memiliki kemampuan dalam menganalisis tagihan isi kurikulum 2013 mata pelajaran sains di SMP yang mengukur keempat aspek tersebut agar dapat menyusun bahan ajar dan LKPD secara baik sesuai dengan tagihan $\mathrm{KD}$ tersebut untuk bisa meningkatkan kemampuan literasi sains peserta didik.

Kemampuan menganalisis tagihan konten standar isi dan menyusun materi ajar dan LKPD untuk meningkatkan kemampau literasi sains merupakan satu keterampilan yang harus dimiliki guru agar tidak salah dalam mengartikan tagihan termasuk juga materi yang harus diberikan kepada siswa agar bisa memenuhi tagihan kompetensi pengetahuan serta cara mengases kemampaun dan keterampilan serta sikap siswa termasuk merencanakan pengalaman belajar yang paling sesuai untuk lebih mempermudah siswa dalam mengembangkan pengetahuan, sikap dan keterampilan dengan baik sesuai dengan tuntutan kurikulum 2013 yang berbasis pada problem based learning, project base learning dan discovery learning. Oleh karena itu untuk mengatasi kekurangan yang dimiliki guru di lapangan dalam kemampuan menganalisis standar isi kurikulum dan menysusun materi ajar serta LKPD maka guru perlu diberikan penyegaran pengetahuan dan keterampilan dalam menyusun bahan ajar dan LKPD yang mendukung pencapaian hasil belajar yang terdapat dalam dokumen kurikulum maupun kemampuan literasi sains seperti idikator yang dikembangkan oleh (Gormally, 2012) terdiri atas: (1) menjelaskan fenomena secara saintifik, (2) mengevaluasi dan merancang penyelidikan ilmiah, (3) menafsirkan data dan bukti secara ilmiah, sehingga para guru IPA memiliki keterampilan yang lebih baik dibandingkan sebelumnya..

Berdasarkan studi awal di lapangan khususnya pada guru IPA di tingkat SMP belum memiliki kemampuan yang baik dalam mendisain bahan ajar dan LKPD yang bisa mengembangkan kemampuan literasi sains peserta didik yang menyangkut: (1) menjelaskan fenomena secara saintifik, (2) mengevaluasi dan merancang penyelidikan ilmiah, (3) menafsirkan data dan bukti secara ilmiah (Gormally, 2012) dan sesuai dengan tagihan implementasi kurikulum yang berlaku agar bisa mengembangkan kemampuan literasi sains tersebut. Hal lain, para guru belum memahami secara komprehensif termasuk hal teknis bagaimana caranya mendisain bahan ajar termasuk LKPD sesuai dengan tagiah kurikukum secara nasional dan internasional. Tagihan mengenai kemampuan mendesian bahan ajar tersebut harus bisa mengembangkan kemampuan literasi sains peserta didik, menurut para guru hal tersebut merupakan hal yang baru yang harus dipahami dikuasai untuk bisa meningkatkan proses dan hasil belajar dari implementasi kurikulum yang berlaku dan meningkatkan kemampuan literasi sains. Juga guruguru yang tersebut harus mampu mengmbangkan konten dan proses serta hasil belajar keterampilan, sebab jika salah dalam menginterpretasinya maka perbaikan proses dan hasil pembelajaran keterampilan khususnya tidak akan sesuai dengan tujuan yang diharapkan.

Dalam pengembangan konten, standar isi nasional pendidikan digunakan sebagai acuan pengembangan konten kurikulum untuk mewujudkan tujuan pendidikan nasional (Peraturan Pemerintah Pemerintah Republik Indonesia Nomor 32 Tahun 2013; Undang-Undang Republik Indonesia Nomor 20 Tahun 2003). Standar tersebut berupa Kompetensi Dasar mencakup sikap sosial, pengetahuan, dan keterampilan dalam muatan mata pelajaran. Kompetensi dasar dikembangkan didasarkan pada prinsip akumulatif, saling memperkuat (reinforced) dan memperkaya (enriched) antar mata pelajaran dan jenjang pendidikan (organisasi horizontal dan vertikal) (Kementrian Pendidikandan Kebudayaan, 2013).

\section{Metode Pelaksanaan}

Tempat pelaksanaan kegiatan PPM di SMPN 5 Mataram sekretariat MGMP IPA Kota Mataram gasal tahun akademik 2019/2020. Model pelaksanaan yang digunakan dalam pengabdian ini adalah workshop, peserta diberikan penjelasan tentang materi Workshop Pengembangan Bahan Ajar dan LKPD IPA Untuk Meningkatkan Kompetensi Literasi Sains dan kemudian diberikan tugas kerja untuk melakukan penyusunan Bahan Ajar dan LKPD. dalam bentuk kelompok. Populasi adalah semua guru SMP anggota MGMP IPA Kota Mataram, sampel yang digunakan sebanyak 40 orang guru. Pengumpulan data dilakukan dengan 
mengevaluasi hasil berupa pengetahun dan keterampilan tentang penyusunan Pengembangan Bahan Ajar dan LKPD IPA Untuk Meningkatkan Kompetensi Literasi Sains. Hasil PPM berupa data skor kuantitatif dan kualitatif dan dianalisis secara deskriptif kualitatif.

\section{Hasil dan Pembahasan}

Hasil pengabdian menunjukan bahwa setelah dilakukan penjelasan dan latihan teknik-teknik pengembangan bahan ajar para guru peserta pengabdian memiliki pemahaman secara komprehensif mengenai teknik-teknik pengembangan bahan ajar yang bisa meningkatkan kemampuan literasi sains peserta didik SMP. Selain itu para peserta tertaruk untuk mebiasakan diri menyususn bahan jar sendiri aagr sesuai dengan konteks kehidupan di masyarakat lokal dan juga internasional.

Dalam mengembangkan kom petensi literasi sains tidak terlepas bagaimana LKPD disusun dan dikembangkan oleh tenaga pendidik yang bisa memenuhi tagihan kurikulum dan sebagai engayaan adalah keterampilan literasi sains. Dari hasil evalausi menunjukan bahwa guru memiliki pemahaman secara baik dan komprehensif mengenai teknik-teknik pengembangan LKPD yang bisa meningkatkan kemampuan literasi sains peserta didik SMP. Aadiharapakan para pesertatersebut miiki keterampilan dalam menysusn dan mengmbangkan LKPD sesuai tagihan literasi sains.

Dari pemberain penjelasan dan latihan menysuun bahan ajar dari kompetensi dsar tertentu Guru terampil dalam mendisain bahan ajar yang bisa meningkatkan kemampuan literasi sains peserta didik SMP. Namun demikian perlu latihan dan bimbingan yang lebih dalam lagi tentang penysusunan bahan ajar dan pengujian acraa baik agar bisa didesimansikan dan bermanfaat bagi guruguru lain anggota MGMP IPA Kota Mataram.

Penysusuna LKPD sangat di pengaruhi oleh sebaikn mana guru memahami tagihan kompetensi dasar pengetahuan dan dan keterampilan serta model pembelajaran eerti apa yang palin $g$ tepat yang bisa dignakan. Dari hasil kegiayan menunjukan bahawa para guru sebagain besar mamiliki keterapilan dalam mendisain LKPD yang bisa meningkatkan kemampuan literasi sains peserta didik SMP. Walau demikian perlu pemantapan yang ebih berkelanjutan untuk emiliki kterampilan yang baik terkait dengan semua tagihan kompetensi pada pata pelajaran IPA SMP.

Hal lain perlu dipahami dan memiliki keterampilan dalam menysusun instrumen pejnilaian literasi sains yang termasuk dalam kelompok soal berpikitir tingkat tinggi. Hasil kegiatan menunjukan bahawa para guru sudah terampil dalam mendisain instrumen asesmen kemampuan literasi sains peserta didik sesuai LKPD. Tetapi masih perlu pendalalamn untuk bisa menysusun instrumen literasi sains yang baik dan sesuai dengan perkembangan sains dan teknologi.

Keterampilan yang perlu dimiliki lagi oleh guru terkait dengan instrumen penialaian sesuai dengan tagihan kompetensi keterampilan, hasil kegiatan menunjukan bahawa sebagian besar sudah mulai terampil dalam mendisain instrumen asesmen keterampilan peserta didik sesuai LKPD yang menuntuk berpikir tingkat tinggi. Namun masih tetap berlatih dalam waktu yang cukup beserta bimbngan dari pihak yang ahli dalam hal tersebut sehingga guru tersebut betul-betul terampil menyusunnya dan busa melaksanakannya secara terus menerus..

Secara keseluruhan kegiatan pengabdian mencapai target dimana para peserta memiliki pemahaman dan keterampilan yang diharapkan sesuai dengan target yang ingin dicapai dari kegiatan pengabdian terse but. Tetapi masih perlu pembimbingan yang memerlukan cukup waktu agar peserta tersebut betul betul memiliki pemhamana dan keterampilan yang diharaakan dari kegiatan pengabdian tersebut. Oleh karena itu kerja sama tim pengabdian dengan MGMP IPA perlu tetap di jaga agar jika ada permasalahn terkait dengan hal tersebut bisa diselesaikan bersama anatra anggota MGMP dan tim pengabdian.

Pemahaman guru peserta pengabdian tentang teknik-teknik pengembangan bahan ajar yang bisa meningkatkan kemampuan literasi sains peserta didik SMP merupakan kompetensi yang baik untuk mendukung peningkatan kualitas proses pembelajaran IPA di SMP di Kota Mataram. Pemahaman tersebut akan terkait dengan perbaikan perencanaan pembelajaran IPA SMP yang akan mencerminkan kualtas pembelajaran. Namun demikian sebaiknya pihak tim pengabdian harus tetap mendampingi para pendidik tersebut agar pemahamannya lebih mendalam dan komprehensif. Disamping yang bersangkutan tetap selalu memperbaharui kontententang literasi sains karena 
definsi konsep literasi sains dan fokus setiap dilakukan asesmen literasi sains.

Cukup baiknya pemahaman guru mengenai teknik-teknik pengembangan LKPD yang bisa meningkatkan kemampuan literasi sains peserta didik SMP adalh asalah satu kompetensi yang harus dimiliki pendidik dalam mengmbangkan kualitas proses pembelajaran sesuai dengan tagihan dari kurikulum yang harus dilaksanakan termasuk dalam mengembangkan kemampuan peserta didik dalam literasi sains. Kompetensi literasi sains tidak bisa dicapai dengan model atau proses pembelajaran yang tidak berbasis pada siswa aktif. Dengan demikian pemahaman teknik bagaimana mengembangkan desain LKPD untuk bisa meningkatkan kompetensi literasi sains peserta didik SMP. Berdasarkan kajian hasil penelitian bahwa untuk meningkatkan kemampuan literasi sains harus dilaksanakan melalui pembelajaran yang mengembangkan kemampuan berpikir tingkat tinggi khususnya berhubungan pemahaman dan keterampilan sains terutama terkait dengan kompetensi literasi sains seperti menginterpretasi data hasil penelitan ilmiah. Selain itu Menurut American Association for the Advancement of Science/AAAS (1993: 322) bahwa kemampuan literasi sains "bisa memperkuat kemampuan dalam persepsi dan refleksi kejadian secara internal yang dapat membuat seseorang memiliki dasar untuk membuat keputusan dan melakukan aksi". Sedangkan OECD (2003b) menyatakan bahwa "literasi sains menekankan tidak hanya pada pengetahuan dan proses ilmiah tetapi menggabungkanya dalam pemahaman".

. Untuk mendukung pencapaian kemampuan literasi sains peserta didik SMP salah satunya adalah terkait dengan kompetensi guru dalam mendesian bahan ajar terutama yang bisa meningkatkan kemampuan literasi sains peserta didik SMP. Kemampuan guru yang sudah baik dalam mendisain bahan ajar merupakan kompetensi yang sangat mendukung peserta didik untuk bisa mencapai kompetensi literasi sains. Tetapi pihak tim pengabdian harus tetap bisa bekerja sama dalam dalam mendisain bahan ajar agar guru betul-betul terampil dalam mendisan bahan ajar tersebut. Keterapilan tersebut harus didukaung pemahaman yang komprehensif tidak hanya terkait dengan konten sains tetapi juga terkait dengan kontekstual sains dalam kehidupan termasuk dalam mengembangkan desain peneilitian ilmiah.

Keterampilan dalam mendisain LKPD yang bisa meningkatkan kemampuan literasi sains peserta didik SMP merupakan komeptensi penting dalam mendukung pencapaian kompetensi dalam menginterpretasi data secara ilmiah dan mengembangkan keterampilan mengevaluasi penelitian ilmiah. Oleh karena itu jika guru sudah memiliki kemampuan tersebut sehingga akan lebih mampu mengembangkan keterampialm peserta didik dalam mendisain penelitian ilmiah dan menginterpretasi data hasil penelitian dan bisa mencapai kemampuan literasi sains sesuai dcengan tujuan yang ingin dicapai.

Keterampilan guru IPA sudah cukup baik dalam mendisain instrumen asesmen kemampuan literasi sains peserta didik sesuai LKPD merupakan satu aspek penting dalam pengukuran tungkat ketercapaian tujuan yang hendak dicaiapi terutama terkait dengan kemampuan literasi sains peserta didik SMP di kota Mataram. Kemampuan tersebut sangat penting dalam memberikan gambaran yang sesungguhnya tentang kemampuan literasi sains jika sebaliknya tidak akan memberikan tingakat dan kuaitas ketercapaian kompetensi sains. Kemampaun tersebut harus tetap dibimbing dan diarahkan oleh tim pengabdian sehingga guru tersebut memiliki keterampilan mendisain instrumen pengukuran tersebut. Juga harus disesuaikan dengan tagihan dari kompetensi literasi sains peserta didik.

Selain kompetensi mendisain instrumen pengukuran literasi sains juga guru peserta pengabdian harus memiliki keterampilan yang cukup baika dalam mendisain instrumen asesmen keterampilan peserta didik sesuai LKPD. Dari hasil pelaksanaan kegiatan pengabdian para guru telah memiliki kompetensi yang baik dalam mengukur keterampilan peserta didik khususnya terkait dengan keterampilan sains di tingkat SMP. Keterampilam tersebut sangat dibutuhkan untuk bisa memberikan gambaran terkait dengan sebaik apa ketercapaian tujuan keterampilan yang harus dimiliki peserta didik.

Pemahaman tentang penyusunan bahan ajar dan LKPD yang bisa meningkatkan kemampuan literasi sain merupakan kompetensi yang diperlukan untuk bisa mendisain rencana pelaksanan pembelajaran yang bisa mendukung kermampaun literasi sains peserta didik tingkat SMP. Selain itu diperlukan keterampilan dalam mendisain bahan ajar dan LKPD yang bisa meningkatkan kemampuan literasi sains untuk mendukung peserta didik dalam mengembangkan pemahamn konten dan keterampilan terkait dengan kompetensi literasi 
sains dan penguatan literasi sains dapat mengembangkan kemampuan menggunakan pengetahuan ilmiah berdasarkan fakta, dan keterampilan yang relevan dengan kehidupan sehari hari, serta penyelesaian secara personal masalah sains (Holbrook dan Rannikmae, 2009)

- Kompetensi lain adalah terkait dengan instrumen evaluasi untuk mengukur tingkat ketercapaian kemampuan literasi sains dan ketermapilan ilmiah dengan harapan bahwa keterampilan tersebut untuk mengukur kemampuan literasi sains peserta didik SMP khususnya di Kota Mataram. Evalausi seharusnya mencakup aspek kemampuan literasi sains yang mencakup "science processes, science concepts, and situation or context" (Harlen, 1999).

\section{Kesimpulan}

Berdasarkan hasil kegiatan pengabdian dapat disimpulkan sebagai berikut: 1) Guru memiliki pemahaman secara komprehensif mengenai teknikteknik pengembangan bahan ajar yang bisa meningkatkan kemampuan literasi sains peserta didik SMP; 2) Guru memiliki pemahaman secara komprehensif mengenai teknik-teknik pengembangan LKPD yang bisa meningkatkan kemampuan literasi sains peserta didik SMP; 3) Guru terampil dalam mendisain bahan ajar yang bisa meningkatkan kemampuan literasi sains peserta didik SMP; 4) Guru terampil dalam mendisain LKPD yang bisa meningkatkan kemampuan literasi sains peserta didik SMP; 5) Guru terampil dalam mendisain instrumen asesmen kemampuan literasi sains peserta didik sesuai LKPD; 6) Guru terampil dalam mendisain instrumen asesmen keterampilan peserta didik sesuai LKPD.

\section{Daftar Pustaka}

American Association for the Advancement of Science/AAAS. (1993). Benchmarks for Science Literacy. Oxford: Oxford University Press.

Gallagher, J.J. (2007). Teaching Science for Understanding a Practical Guide for Middle and High School Teacher. Ohio: Pearson Merrill Prentice Hall.

Gormally, C. 2012. Devloping a Test of Scientific Literacy Skills (TOSLS): Maesuring
Undergraduates' Evaluation of Information and Arguments. CBE Life Sci Educ. 11(4): 364-377

Harlen, W. (1999). The Assessment of Scientific Literacy within the Pisa. [Online] Tersedia: www.pisa.oecd.org. [2 Juni 2018].

Holbrook, J. dan Rannikmae, M. (2009). "The Meaning of Scientific Literacy" International Journal of Environment \& Science Education. 4, (3), 275-288.

Kementrian Pendidikan dan Kebudayaan. 2013. Peraturan Menteri Pendidikan dan Kebudayaan Republik Indonesia Nomor 66 Tahun 2013 tentang Standar Penilaian Pendidikan.

Martin, M.O., et al. (2000). TIMSS International Scince Report. Boston: The International Study Center Boston College. [Online] Tersedia:

http://timssandpirls.bc.edu/timss1999i/pdf/T9 9i Sci All.pdf. [18 April 2018].

Organization for Economic Co-operation and Development /OECD. (2010). PISA 2009 Results: What Students Know and Can Do Student Performance in Reading, Mathematics and Science (Volume I). OECD publications. [Online]. Tersedia: http://browse.oecdbookshop.org/oecd/pdfs/br owseit/9810071E.PDF. [24 Maret 2018].

Organization for Economic Co-operation and Development/OECD. (2003b). The PISA 2003 Assessment Framework-Mathematics, Reading, Science and Problem Solving Knowlwdge and Skill. Paris.

Organization for Economic Co-operation and Development/OECD. (2007). PISA 2006 Science Competencies for Tomorrow's World Volume 1- Analysis. Danvers: OECD Publishing. [Online]. Tersedia: http://www.oecd.org/dataoecd/30/17/397032 67.pdf. [ 24 Desember 2018].

Pemerintah Republik Indonesia (2003). UndangUndang Republik Indonesia Nomor 20 Tahun 2003 Tentang Sistem Pendidkan Nasiona.

Pemerintah Republik Indonesia (2013). Peraturan Pemerintah Pemerintah Republik Indonesia Nomor 32 Tahun 2013; Tentang Standar Nasional Pendidikan.

Rustaman, N.Y. (2010). Literasi Sains Anak Indonesia 2000 dan 2003. [Online] Tersedia: http://file.upi.edu/Direktori/SPS/PRODI. 
PENDIDIKAN_IPA/195012311979032-

NURYANI_RUSTAMAN/MAKALAH_

LITSAINS 2003 sep,06.pdf. 1-20. [1 Maret 2018]. 